\title{
Nipah Virus Transmission from Bats to Humans Associated with Drinking Traditional Liquor Made from Date Palm Sap, Bangladesh, 2011-2014
}

\author{
M. Saiful Islam, Hossain M.S. Sazzad, Syed Moinuddin Satter, Sharmin Sultana, \\ M. Jahangir Hossain, Murshid Hasan, Mahmudur Rahman, Shelley Campbell, \\ Deborah L. Cannon, Ute Ströher, Peter Daszak, Stephen P. Luby, Emily S. Gurley
}

Nipah virus (NiV) is a paramyxovirus, and Pteropus spp. bats are the natural reservoir. From December 2010 through March 2014, hospital-based encephalitis surveillance in Bangladesh identified 18 clusters of NiV infection. The source of infection for case-patients in 3 clusters in 2 districts was unknown. A team of epidemiologists and anthropologists investigated these 3 clusters comprising 14 case-patients, 8 of whom died. Among the 14 case-patients, 8 drank fermented date palm sap (tari) regularly before their illness, and 6 provided care to a person infected with NiV. The process of preparing date palm trees for tari production was similar to the process of collecting date palm sap for fresh consumption. Bat excreta was reportedly found inside pots used to make tari. These findings suggest that drinking tari is a potential pathway of NiV transmission. Interventions that prevent bat access to date palm sap might prevent tariassociated NiV infection.

$\mathrm{N}$ ipah virus $(\mathrm{NiV})$ is a bat-borne emerging infection, and Pteropus spp. bats are the wildlife reservoir (1). $\mathrm{NiV}$ was discovered in an outbreak in Malaysia in 1998 that affected 283 persons and caused 109 deaths (case-fatality rate $39 \%$ ) (2). Subsequently, outbreaks of NiV infection have occurred nearly every year in Bangladesh and occasionally in India $(1,3-5)$. A total of 33 outbreaks of $\mathrm{NiV}$

Author affiliations: icddr,b, Dhaka, Bangladesh (M.S. Islam,

H.M.S. Sazzad, S.M. Satter, M.J. Hossain, M. Hasan,

S.P. Luby, E.S. Gurley); Institute of Epidemiology Disease

Control and Research, Dhaka (S. Sultana, M. Rahman);

Medical Research Council, London, United Kingdom

(M.J. Hossain); Centers for Disease Control and Prevention,

Atlanta, Georgia, USA (S. Campbell, D.L. Cannon, U. Ströher);

EcoHealth Alliance, New York, New York, USA (P. Daszak);

Stanford University Center for Innovation in Global Health,

Stanford, California, USA (S.P. Luby)

DOI: http://dx.doi.org/10.3201/eid2204.151747 encephalitis were reported in Bangladesh and India during 2001-2014, and epidemiologic investigations implicated batborne and human-to-human transmission $(6,7)$. During 2004-2012, a total of $157 \mathrm{NiV}$ infections were reported in Bangladesh, and $22 \%$ of these occurred through human-tohuman transmission $(8)$.

Investigations of $\mathrm{NiV}$-associated outbreaks in Bangladesh identified consumption of fresh date palm sap as the primary route of bat-to-human transmission $(1,9)$. In Bengali culture, sap harvested from the date palm tree is commonly used for fresh consumption and fermentation $(10,11)$. Moreover, in Asia, Australia, and Africa, fermented date palm sap is used to make alcoholic drinks, known as toddy, tari, or palm wine $(12,13)$. In Bangladesh, date palm sap is typically collected in clay pots that are attached to the tree. A top section of the date palm tree bark is shaved, allowing the sap to ooze overnight into the collection pot (11). A previous NiV study reported that Pteropus spp. bats frequently feed on the shaved bark and often contaminate the sap with saliva, urine, and excreta (14). Pteropus spp. bats are also known to occasionally shed NiV in their secretions and excretions $(15,10)$.

Since 2006, the Institute of Epidemiology, Disease Control, and Research (IEDCR) in Dhaka, Bangladesh, under the Ministry of Health and Family Welfare of Bangladesh, has collaborated with the International Centre for Diarrhoeal Diseases Research, Bangladesh (icddr,b), Dha$\mathrm{ka}$, on hospital-based encephalitis surveillance in the areas where NiV-associated outbreaks have been reported (3). From December 2010 through March 2014, the surveillance identified 18 clusters of NiV infection; in 15 of these clusters, the index case-patients had exposure to fresh date palm sap before illness onset. For the remaining 3 clusters, the index case-patients had no known contact with date palm saps, bats, or sick animals other than bats. Recognizing the potential for new pathways of transmission, we investigated 
other possible exposures to $\mathrm{NiV}$ by applying epidemiologic and anthropological approaches in our study of these $3 \mathrm{NiV}$ disease clusters. We used the epidemiologic study to explain the proximate individual-level factors linked to the disease outbreak (17) and an anthropological approach to explicate local perceptions, behaviors, and practices that might have contributed to the disease occurrence (18). Therefore, the objectives of our investigation were to describe the clinical signs and symptoms of the case-patients and determine the possible route of transmission for these clusters.

\section{Methods}

The team conducted this study during 2011-2014 in Rajshahi and Rangpur Districts, Bangladesh. Surveillance physicians from Rangpur Medical College Hospital and Rajshahi Medical College Hospital identified suspected case-patients (Table), recorded clinical histories and home addresses, and collected whole blood samples from each. The serum was separated from each sample, stored in liquid nitrogen at the hospital, and then transported to IEDCR (3). The laboratory team at IEDCR tested serum samples for $\mathrm{NiV} \operatorname{IgM}$ and $\operatorname{IgG}$ by using IgM-capture and indirect IgG enzyme immunoassays $(19,21)$.

On the basis of type of exposure, we categorized suspected case-patients as primary or secondary case-patients, and these two groups were further categorized as case-patients with probable or laboratory-confirmed $\mathrm{NiV}$ infection (Table). To identify a potential NiV infection cluster, surveillance physicians asked each of the admitted suspected

Table. Case definitions for Nipah virus (NiV) infections that occurred in 3 clusters, Rangpur and Rajshahi Districts, Bangladesh, 2011, 2012, and 2014

\begin{tabular}{ll}
\hline Type of case & Case definition \\
\hline Suspected & $\begin{array}{l}\text { Fever or history of fever with axillary } \\
\text { temperature }>38.5^{\circ} \mathrm{C} \text {, altered mental } \\
\text { status, new onset of seizures, or a new } \\
\text { neurologic deficit in a patient from an } \\
\text { adult or pediatric ward of an NiV } \\
\text { surveillance hospital during the NiV } \\
\text { season (3). }\end{array}$ \\
\hline Illness meeting the case definition for \\
suspected NiV infection in a person who \\
lived in the same village as a person with \\
laboratory-confirmed NiV infection but \\
who died before specimens could be \\
collected for diagnosis (19).
\end{tabular}

case-patients and their caregivers present in the hospital about other sick persons or persons in their communities who had recently died with similar symptoms. We defined a $\mathrm{NiV}$ infection cluster as $\geq 2$ suspected meningoencephalitis case-patients living within 30 minutes' walking distance from each other who had onset of similar illnesses within 3 weeks of one another or had epidemiologic linkages to one another (22).

After identifying laboratory-confirmed $\mathrm{NiV}$ infection cases (Table), the team reviewed hospital records, took preliminary information from the surveillance physicians, and visited case-patients from each cluster within a month of case confirmation. We limited this study to clusters in which no case-patients had a history of drinking fresh date palm sap. In the community, the team used a structured questionnaire to interview surviving case-patients and the friends, relatives, and neighbors of deceased case-patients as proxy respondents. The team collected information related to exposure and signs and symptoms of illness to determine routes of $\mathrm{NiV}$ transmission for each case-patient.

The team visited the households of case-patients and used culturally appropriate approaches to build rapport and trust with the community (23). The team conducted in-depth interviews and group discussions with surviving case-patients and the family caregivers, friends, and neighbors of the deceased to explore the exposure histories of each case-patient by using an open-ended interview guide. Open-ended questions allowed the interviewers to obtain new insights about the outbreak. Good rapport with community members helped the team collect information on potentially sensitive issues, such as alcohol consumption (24), which is prohibited among the majority Muslim population of Bangladesh. The preliminary data collected during this study suggested that the case-patients might have consumed tari before their illness onset. Therefore, the team also interviewed 5 date palm sap harvesters and conducted 3 group discussions with community members to learn about tari production, consumption, and selling practices in the affected communities. The team also collected and analyzed whole blood samples from surviving case-patients and from nonpatients (defined as persons in the community who drank tari with the case-patients but did not experience any symptoms) by using the same methods described above.

\section{Data Analysis}

We used descriptive statistics to characterize the demographic and clinical characteristics of the case-patients. The team expanded the observation and interview field notes and summarized them. The primary author (M.S.I.) read summaries of the interviews and identified themes. These themes were shared among investigators for review and consensus. The primary author then categorized the data 
according to the selected themes, consistent with methods previously described (25).

\section{Ethical Considerations}

The team obtained verbal informed consent from study participants. The surveillance and outbreak investigation study protocol was reviewed and approved by the ICDDR,B Ethical Review Committee.

\section{Results}

Three clusters were identified, consisting of 14 case-patients ( 9 with confirmed NiV infection, 5 with probable $\mathrm{NiV}$ infection). Eight of the 14 case-patients were primary case-patients ( 3 with confirmed $\mathrm{NiV}$ infection, 5 with probable NiV infection). All 6 of the secondary case-patients had confirmed NiV infection. Among the 14 casepatients, 7 had illness onset during January-March 2011 in Rangpur District (first cluster), 3 had illness onset in February 2012 in Rajshahi District (second cluster), and 4 had illness onset during January-February 2014 in Rangpur District (third cluster). Eight drank tari before their illness onset, whereas 6 only had exposure to other casepatients. None of the primary case-patients had any history of drinking fresh date palm sap or exposure to sick humans or animals. All of the illnesses began with fever. All 8 of the primary case-patients had altered mental status followed by loss of consciousness and death. The median duration from illness onset to death was 6 days. All 6 secondary case-patients survived. The median age of all 14 case-patients was 32 years. All the primary case-patients were male, and all the secondary case-patients were female. None of the non-case-patients had NiV IgM or IgG detected in their serum samples.

In the 2011 Rangpur cluster, case-patients A, B, C, and $\mathrm{G}$ drank tari regularly in the evenings, and the sap to make tari was collected from a single village (Figure). Case-patients $A$ and $G$ were family friends and lived in the same village. Case-patients $\mathrm{B}$ and $\mathrm{C}$ were also related and lived in the same village. Case-patients D, E, and F were family caregivers of case-patient $\mathrm{C}$ and provided close-contact care during his illness. All 3 family caregivers experienced illness within 2 weeks of case-patient C's illness onset.

In the 2012 Rajshahi cluster, case-patient $\mathrm{H}$ was a tari producer and harvester of date palm sap. Case-patient I was a neighbor and cousin of case-patient $\mathrm{H}$, and both drank tari regularly in the evenings. They drank tari together from the same pot 6 days before their illness onsets. Casepatient $\mathbf{J}$ was a family caregiver of patient $\mathrm{H}$ and provided close-contact care during his illness. She experienced fever 11 days after case-patient H's illness onset.

In the 2014 Rangpur cluster, the respondents reported that case-patients $\mathrm{K}$ and $\mathrm{L}$ were family friends and had drunk tari every day in the evenings before their illness onsets (Figure). Case-patient L became ill after 5 days after case-patient $\mathrm{K}$, and case-patient $\mathrm{L}$ did not have any contact with case-patient $\mathrm{K}$ while case-patient $\mathrm{K}$ was ill. The tari they drank was collected from the same village where the 2011 Rangpur cluster was identified. Case-patients $M$ and $\mathrm{N}$ shared the same bed with case-patient $\mathrm{L}$ at home; casepatient $\mathrm{N}$ was a family caregiver to case-patient $\mathrm{L}$, providing close-contact care for him at home and in the hospital. Case-patient $\mathrm{M}$ had onset of fever 12 days later, and casepatient $\mathrm{N}$ had onset of fever 14 days after case-patient L's illness onset.

\section{Tari Production, Processing, and Selling Patterns in Rangpur and Rajshahi}

The area of Rangpur where the case-patients lived was well known for its tari production and was the largest tariproducing area in the district. An estimated 500 date palm trees grow in the area, which produces and supplies tari throughout the district. Tari retailers from different subdistricts of Rangpur also come to this area to buy tari at a wholesale price. In the affected villages, the tari producers reported that they had been leasing all the date palm trees for several years. Villagers reported they did not have regular access to fresh date palm sap because almost all the date palm sap from the village was made into tari.

In the NiV-affected area of Rajshahi, the tari is produced in small quantities. An estimated 15 date palm trees

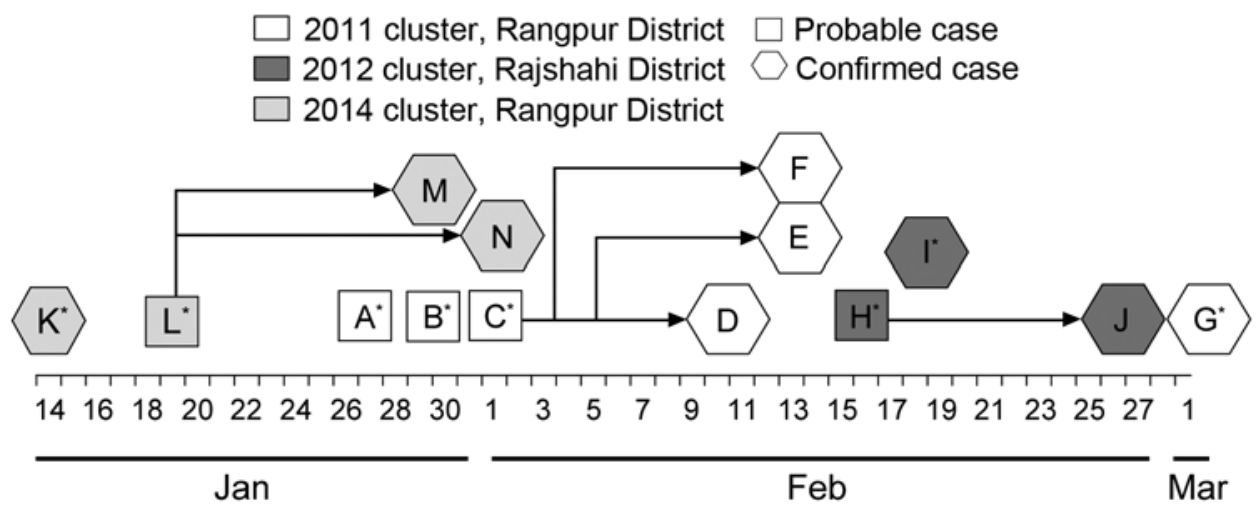

Figure. Timeline of illness onset in persons with primary and secondary cases of Nipah virus infection that occurred in 3 clusters, Rangpur and Rajshahi Districts, Bangladesh, 2011, 2012, and 2014. Asterisks indicate primary cases; cases without an asterisk are secondary cases. 
grow in the affected community of Rajshahi. The tari producer leases these trees only during winter to produce tari.

The tari production process was identical in each of the affected communities. The process of preparing the date palm trees for tari production was similar to the process for collecting date palm sap for fresh consumption (11). To prepare the tree for tapping, the sap harvesters cut the old leaves close to the top of the trees with a knife to expose the tender part of the tree. To tap the tree, the harvesters shave a V-shaped cut at the top of the tree and set a bamboo spigot at the end of the cut. After 3-5 days, the $\mathrm{V}$ cut is shaved again, and an earthen pot is hung under the spigot to catch the sap that oozes out. For fresh date palm sap, the harvesters need to clean and dry the sap collection pots after each episode of sap collection. However, tari harvesters from both affected communities reported that they use the same earthen pot for sap collection for several days without cleaning it so that yeast can form at the bottom of the earthen pot. Yeast aids the fermentation of the fresh date palm sap in the pot.

In Rangpur, the date palm sap is harvested for tari year round. The harvesters reported that date palm sap can be collected from each tree for 3-4 days a week for 4 months at a time, and then the tree is left to recover for the next 7-8 months. The harvesters stagger the tapping of trees so there is a continuous supply of date palm sap to make tari throughout the year. The harvesters reported that they harvest more sap during winter than during other seasons because of higher demand for tari from consumers. Moreover, they reported that the sap flows more freely from each tree during the winter. In the affected communities, the harvesters reported that every day from $8 \mathrm{a} . \mathrm{m}$. until noon, they collect the sap from the hanging earthen pots and accumulate the collected sap in other earthen pots or containers and leave the hanging pots on the trees. In Rangpur, the harvesters bring tari to their house and immediately sell it to retailers and consumers from morning until late at night. Occasionally, consumers take tari away with them in plastic bottles. In the affected area of Rajshahi, after being removed from the trees, the tari pots are kept in a betel leaf garden, and the harvesters sell tari from there.

The tari sellers and harvesters reported that tari consumers are men and included truck and bus drivers, day laborers, rickshaw pullers, and local farmers. They also reported that tari is less expensive than other illegal alcohol available for sale and that making tari is less laborious than collecting fresh date palm sap because harvesters do not need to clean and dry the earthen pots after each collection. They added that making tari is more profitable than selling fresh date palm sap. During our visit to communities near to the affected areas in Rangpur, the price of fresh date palm sap was $\$ 0.20$ per liter, and the price of tari was $\$ 0.50$ per liter. The price differential provides an incentive for making tari.
We observed bat roosts in the affected community of Rangpur, and date palm sap harvesters reported that they frequently observe bats flying near the date palm trees. The harvesters reported that they often find bat excreta in and on the sap pots. The harvesters reported filtering tari with a net or cloth before selling it to remove the excreta. In Rajshahi, the villagers reported that there is no bat roost in their community. However, they reported seeing bats visiting date palm trees at night. None of the harvesters in Rajshahi reported filtering tari before selling it to consumers.

\section{Discussion}

The laboratory, clinical, and qualitative findings in this study suggest that the 14 case-patients in the 3 clusters we investigated were infected with $\mathrm{NiV}$. The primary NiV casepatients identified in the clusters drank tari regularly in the evenings before their illness onsets, and none of them had a history of fresh date palm sap consumption or any exposure to other NiV case-patients, which were the main transmission pathways for NiV infection identified in previous outbreak investigations in Bangladesh (9,26). Moreover, none of the case-patients had exposure to sick animals, another possible pathway for $\mathrm{NiV}$ transmission reported in studies conducted in Malaysia and Singapore (27).

Tari is a date palm sap product. Because tari fermentation was a continuous process and date palm sap was fermented inside the tari pots while they were hanging in the trees, some date palm sap added to the tari might technically be fresh sap. However, the primary case-patients probably did not consume fresh date palm sap because tari was collected from 8 a.m. to noon but the primary case-patients drank tari only in the evening, which suggests that all the sap they consumed was at least partially fermented by the time of consumption. Findings from this investigation suggest that drinking tari is a potential source of $\mathrm{NiV}$ infection in Bangladesh. Investigators in India had similar findings during an outbreak reported in 2007 in West Bengal near the border with Bangladesh (4). They reported that drinking fermented date palm sap possibly contaminated with bats excreta and secretions was the source of $\mathrm{NiV}$ infection for the index patient, which further supports our assertion that NiV infection from drinking tari is plausible (4). Moreover, 2 clusters in this study were traced back to the same tari production village in Rangpur, further strengthening the conclusion that tari was the mode of transmission.

Previous studies have shown that fruit bats frequently lick the date palm sap and occasionally urinate inside collection pots (14). In our investigation, the reported evidence of bats visiting date palm trees, the presence of bat excreta inside tari pots, the reported use of the same pot for several days without cleaning, and the accumulation of sap from multiple pots into 1 pot suggest that sap is probably contaminated with bat urine or saliva during collection and 
fermentation. NiV can survive up to 4 days in bat urine and at least 1 day in sap contaminated with bat urine when kept at an average temperature of $19^{\circ} \mathrm{C}(28)$. A study to determine viability of $\mathrm{NiV}$ in artificial palm sap contaminated with NiV (strain Bangladesh/200401066) found no statistically significant reduction in $\mathrm{NiV}$ titers for at least 7 days when kept at a temperature of $22^{\circ} \mathrm{C} \mathrm{(29).} \mathrm{Generally,} \mathrm{envel-}$ oped and thus lipophilic viruses like $\mathrm{NiV}$ are susceptible to alcohol. A $60 \%-70 \%$ alcohol solution is recommended for sterilizing contaminated objects (30). A study conducted in India showed that tari derived naturally from fermenting date palm sap contains $5 \%-8 \%$ alcohol and has a $\mathrm{pH}$ of 4.5-6.0 (12). This 5\%-8\% alcohol concentration might not have been high enough or sufficiently distributed throughout the tari to sterilize the $\mathrm{NiV}$, thus allowing persistence of viable virus and transmission of $\mathrm{NiV}$ to tari consumers during the winter months, when the ambient temperature ranges from $15^{\circ} \mathrm{C}$ to $28^{\circ} \mathrm{C}(21)$.

In Bangladesh, family caregivers commonly provide close-contact care to hospitalized patients (31). Infected patients often shed the virus through body secretions and excretions and can contaminate foods and surfaces, including bed rails, bed sheets, and towels $(32,33)$. Close contact is the most likely route through which family caregivers became infected (26). Family caregivers identified in this study had direct contact with primary case-patients and their body secretions.

The findings of our study are subject to limitations. First, some participants may have been reluctant to report production, consumption, and selling of tari because these are illegal activities in Bangladesh. Initially, some of the date palm sap harvesters and tari producers were reluctant to share information with us. However, the social scientists on the investigation team built rapport and trust with the respondents, which encouraged the respondents to share sensitive information (23). Thus, the hesitance to disclose behaviors related to tari probably did not have a substantial effect on our findings. Second, no control group was available. Without a comparison group, we were unable to determine if our primary casepatients were more likely than other persons residing in these villages to drink tari. However, given the absence of evidence that the primary case-patients had other contact with bats, sick animals, or persons with NiV infection, consumption of tari appears to be the most likely transmission route. Third, we interviewed family members and friends of the deceased case-patients as proxy respondents to ascertain case exposures. However, during outbreaks of fatal diseases such as NiV infection (with a case-fatality rate $>70 \%$ ), there is no alternative to this approach (20). Since 2003, we have interviewed proxy respondents for case-exposures in every $\mathrm{NiV}$-associated outbreak investigation conducted in Bangladesh $(3,9,19)$. Fourth, because of the delays in investigation of the 2011 cluster, our definition for a confirmed cases of NiV infection was based on the presence of NiV IgM or IgG in serum samples. Confirming a case based on the presence of $\operatorname{IgG}$ is reasonable, however, because all the family caregivers from the 2011 Rangpur cluster had illness onset within 2 weeks after contact with a case-patient (19).

Because harvesting date palm sap for tari production is similar to harvesting it for consumption of fresh date palm sap, the intervention of using bamboo skirts to cover the shaved part of the date palm tree and the sap collection pots to prevent bat contact and possible $\mathrm{NiV}$ introduction is worth exploring. The use of bamboo skirts is already a successful, affordable, and culturally acceptable method to prevent bat access to date palm sap, and this strategy could also be used to prevent $\mathrm{NiV}$ transmission from tari consumption $(34,35)$. In addition, tari harvesters from ethnic minority communities have limited access to mass media because of their ethnic, religious, and linguistic minority status in Bangladesh. Efforts should be made to raise their awareness about strategies that interrupt bat access to date palm sap. At this time, we are not aware of any studies that have tested the survival of $\mathrm{NiV}$ in tari. As a next step, we recommend testing NiV survival in tari at different levels of alcohol concentration.

All 3 of the clusters of NiV infection that we investigated were linked to drinking tari. Drinking tari might also be a route of exposure for other batborne viruses. A total of 55 newly described viruses from 7 virus families were recently identified in urine and saliva from Pteropus spp. bats in Bangladesh (36), suggesting that these bats could also contaminate tari with other viruses that could cause disease in humans. Date palm sap is harvested for fermentation in many areas where Pteropus spp. bats and other fruit bats are native, including Australia, Asia, and Africa (37-40). Consumers of fermented drinks and other date palm products that are harvested using similar processes as in Bangladesh might be at risk for NiV infection and other batborne diseases $(12,13,36)$.

\section{Acknowledgments}

We thank all the study participants for their time and support. Diana Diaz-Granados deserves special thanks for her contributions in reviewing the manuscript.

The study was funded by the US Centers for Disease Control and Prevention (CDC) cooperative agreement no. 5U01CI000628-01, the US National Institutes of Health (NIH) grant no. 07-0150712-52200 (Bangladesh-NIH/Emerging Infectious Disease), and National Science Foundation/NIH Ecology and Evolution of Infectious Diseases grant no. 2R01-TW005869 from the Fogarty International Center. ICDDR,B also acknowledges with gratitude the commitment of CDC, NIH, and the government of 
Bangladesh to its research efforts. icddr, $b$ is also grateful to the governments of Australia, Bangladesh, Canada, Sweden, and the United Kingdom for providing core/unrestricted support.

Mr. Islam is a social scientist working with the Centre for Communicable Diseases at icddr,b. His research interests include zoonotic diseases, emerging and reemerging infectious diseases, cultural epidemiology, infection control, and prevention in hospital and community settings.

\section{References}

1. Luby SP. The pandemic potential of Nipah virus. Antiviral Res. 2013;100:38-43. http://dx.doi.org/10.1016/j.antiviral.2013.07.011

2. Chua KB. Nipah virus outbreak in Malaysia. J Clin Virol. 2003; 26:265-75. http://dx.doi.org/10.1016/S1386-6532(02)00268-8

3. Sazzad HM, Hossain MJ, Gurley ES, Ameen KM, Parveen S, Islam MS, et al. Nipah virus infection outbreak with nosocomial and corpse-to-human transmission, Bangladesh. Emerg Infect Dis. 2013;19:210-7. http://dx.doi.org/10.3201/eid1902.120971

4. Arankalle VA, Bandyopadhyay BT, Ramdasi AY, Jadi R, Patil DR, Rahman M, et al. Genomic characterization of Nipah virus, West Bengal, India. Emerg Infect Dis. 2011;17:907-9. http://dx.doi.org/ 10.3201/eid1705.100968

5. Chadha MS, Comer JA, Lowe L, Rota PA, Rollin PE, Bellini WJ, et al. Nipah virus-associated encephalitis outbreak, Siliguri, India. Emerg Infect Dis. 2006;12:235-40. http://dx.doi.org/10.3201/ eid1202.051247

6. World Health Organization. Nipah virus outbreaks in the WHO South-East Asia Region. Surveillance and outbreak alert [cited $2015 \mathrm{Feb} 25]$. http://www.searo.who.int/entity/emerging_diseases/ links/nipah_virus_outbreaks_sear

7. Institute of Epidemiology, Disease Control, and Research. Nipah outbreak-2014 [cited 2015 Apr 7]. http://www.iedcr.org/ index.php?option $=$ com_content\&view $=$ article $\& i d=106$

8. Hegde ST, Sazzad HM, Hossain MJ, Kenah E, Daszak P, Rahman M, et al. Risk factor analysis for Nipah infection in Bangladesh, 2004 to 2012. Presented at: 62nd Annual Meeting of the American Journal of Tropical Medicine and Hygiene 2013; 2013 Nov 13-17; Washington, DC, USA.

9. Luby SP, Rahman M, Hossain MJ, Blum LS, Husain MM, Gurley E, et al. Foodborne transmission of Nipah virus, Bangladesh. Emerg Infect Dis. 2006;12:1888-94. http://dx.doi.org/10.3201/eid1212.060732

10. Annett HE, Lele GK, Amin BM. The date sugar industry in Bengal: an investigation into its chemistry and agriculture. London: W. Thacker \& Co; 1913.

11. Nahar N, Sultana R, Gurley ES, Hossain MJ, Luby SP. Date palm sap collection: exploring opportunities to prevent Nipah transmission. EcoHealth. 2010;7:196-203. http://dx.doi.org/ 10.1007/s10393-010-0320-3

12. Chandrasekhar K, Sreevani S, Seshapani P, Pramodhakumari J. A review on palm wine. Int J Res Biol Sci. 2012;2:33-38.

13. Zaid A. Origin, geographical distribution, and nutritional values of date palm. In: Zaid A, editor. Date palm cultivation. Rome: Food and Agricultural Organization of the United Nations; 2002.

14. Khan MS, Hossain J, Gurley ES, Nahar N, Sultana R, Luby SP. Use of infrared camera to understand bats' access to date palm sap: implications for preventing Nipah virus transmission. EcoHealth. 2010;7:517-25. http://dx.doi.org/10.1007/s10393-010-0366-2

15. Chua KB, Koh CL, Hooi PS, Wee KF, Khong JH, Chua BH, et al. Isolation of Nipah virus from Malaysian Island flying-foxes. Microbes Infect. 2002;4:145-51. http://dx.doi.org/10.1016/ S1286-4579(01)01522-2
16. Wacharapluesadee S, Lumlertdacha B, Boongird K, Wanghongsa S, Chanhome L, Rollin P, et al. Bat Nipah virus, Thailand. Emerg Infect Dis. 2005;11:1949-51. http://dx.doi.org/ 10.3201/eid1112.050613

17. McMichael AJ. Prisoners of the proximate: loosening the constraints on epidemiology in an age of change. Am J Epidemiol. 1999;149:887-97. http://dx.doi.org/10.1093/ oxfordjournals.aje.a009732

18. Islam MS, Luby SP, Gurley ES. Developing culturally appropriate interventions to prevent person-to-person transmission of Nipah virus in Bangladesh: cultural epidemiology in action. In: Banwell C, Ulijaszek S, Dixon J, editors. When culture impacts health: global lessons for effective health research. London: Elsevier; 2013.

19. Hsu VP, Hossain MJ, Parashar UD, Ali MM, Ksiazek TG, Kuzmin I, et al. Nipah virus encephalitis reemergence, Bangladesh. Emerg Infect Dis. 2004;10:2082-7. http://dx.doi.org/10.3201/ eid1012.040701

20. Luby SP, Hossain MJ, Gurley ES, Ahmed BN, Banu S, Khan SU, et al. Recurrent zoonotic transmission of Nipah virus into humans, Bangladesh, 2001-2007. Emerg Infect Dis. 2009;15:1229-35. http://dx.doi.org/10.3201/eid1508.081237

21. Rahman MA, Hossain MJ, Sultana S, Homaira N, Khan SU, Rahman M, et al. Date palm sap linked to Nipah virus outbreak in Bangladesh, 2008. Vector Borne Zoonotic Dis. 2012;12:65-72. http://dx.doi.org/10.1089/vbz.2011.0656

22. Naser AM, Hossain MJ, Sazzad HM, Homaira N, Gurley ES, Podder G, et al. Integrated cluster- and case-based surveillance for detecting stage III zoonotic pathogens: an example of Nipah virus surveillance in Bangladesh. Epidemiol Infect. 2015;143:1922-30. http://dx.doi.org/10.1017/S0950268814002635

23. Schulman-Green D, McCorkle R, Bradley EH. Tailoring traditional interviewing techniques for qualitative research with seriously ill patients about the end-of-life: a primer. Omega (Westport). 2010;60:89-102. http://dx.doi.org/10.2190/OM.60.1.e

24. Varkevisser CM, Pathmanathan I, Brownlee A. Designing and conducting health systems research projects. Amsterdam: KIT Publishers; 2003.

25. Bradley EH, Curry LA, Devers KJ. Qualitative data analysis for health services research: developing taxonomy, themes, and theory. Health Serv Res. 2007;42:1758-72. http://dx.doi.org/10.1111/ j.1475-6773.2006.00684.x

26. Gurley ES, Montgomery JM, Hossain MJ, Bell M, Azad AK, Islam MR, et al. Person-to-person transmission of Nipah virus in a Bangladeshi community. Emerg Infect Dis. 2007;13:1031-7. http://dx.doi.org/10.3201/eid1307.061128

27. Chowdhury S, Khan SU, Crameri G, Epstein JH, Broder CC, Islam A, et al. Serological evidence of henipavirus exposure in cattle, goats and pigs in Bangladesh. PLoS Negl Trop Dis. 2014;8:e3302. http://dx.doi.org/10.1371/journal.pntd.0003302

28. Fogarty R, Halpin K, Hyatt AD, Daszak P, Mungall BA. Henipavirus susceptibility to environmental variables. Virus Res. 2008;132:140-4. http://dx.doi.org/10.1016/j.virusres.2007.11.010

29. de Wit E, Prescott J, Falzarano D, Bushmaker T, Scott D, Feldmann H, et al. Foodborne transmission of Nipah virus in Syrian hamsters. PLoS Pathog. 2014;10:e1004001. http://dx.doi.org/10.1371/journal.ppat.1004001

30. Boyce JM, Pittet D. Guideline for hand hygiene in health-care settings. recommendations of the Healthcare Infection Control Practices Advisory Committee and the HICPAC/SHEA/ APIC/IDSA Hand Hygiene Task Force. MMWR Recomm Rep. 2002;51(RR-16):1-45.

31. Islam MS, Luby SP, Sultana R, Rimi NA, Zaman RU, Uddin M, et al. Family caregivers in public tertiary care hospitals in Bangladesh: risks and opportunities for infection control. Am J Infect Control. 2014;42:305-10. http://dx.doi.org/10.1016/j.ajic.2013.09.012 
32. Chua KB, Lam SK, Goh KJ, Hooi PS, Ksiazek TG, Kamarulzaman A, et al. The presence of Nipah virus in respiratory secretions and urine of patients during an outbreak of Nipah virus encephalitis in Malaysia. J Infect. 2001;42:40-3. http://dx.doi.org/10.1053/jinf.2000.0782

33. Hassan MZ, Sturm-Ramirez K, Sazzad HM, Bhuiyan MU, Rahman M, Rahman MZ, et al. Shedding of Nipah virus and contamination of hospital surfaces during an outbreak in Bangladesh, 2013-2014. Presented at: International Conference on Emerging Infectious Diseases 2015; 2015 Aug 24-26; Atlanta, Georgia, USA.

34. Khan SU, Gurley ES, Hossain MJ, Nahar N, Sharker MA, Luby SP. A randomized controlled trial of interventions to impede date palm sap contamination by bats to prevent Nipah virus transmission in Bangladesh. PLoS One. 2012;7:e42689. http://dx.doi.org/10.1371/ journal.pone. 0042689

35. Nahar N, Mondal UK, Sultana R, Hossain MJ, Khan MS, Gurley ES, et al. Piloting the use of indigenous methods to prevent Nipah virus infection by interrupting bats' access to date palm sap in Bangladesh. Health Promot Int. 2013;28:378-86. http://dx.doi.org/10.1093/heapro/das020
36. Anthony SJ, Epstein JH, Murray KA, Navarrete-Macias I, Zambrana-Torrelio CM, Solovyov A, et al. A strategy to estimate unknown viral diversity in mammals. MBio. 2013;4:e00598-13. http://dx.doi.org/10.1128/mBio.00598-13

37. Leroy EM, Kumulungui B, Pourrut X, Rouquet P, Hassanin A, Yaba P, et al. Fruit bats as reservoirs of Ebola virus. Nature. 2005;438:575-6. http://dx.doi.org/10.1038/438575a

38. Field H, de Jong C, Melville D, Smith C, Smith I, Broos A, et al. Hendra virus infection dynamics in Australian fruit bats. PLoS One. 2011;6:e28678. http://dx.doi.org/10.1371/ journal.pone. 0028678

39. Mbuagbaw L, Noorduyn SG. The palm wine trade: occupational and health hazards. Int J Occup Environ Med. 2012;3:157-64.

40. Nowak RM. Walker's bats of the world. Baltimore: The John Hopkins University Press; 1994.

Address for correspondence: M. Saiful Islam, Centre for Communicable Diseases, icddr,b, 68 Tajuddin Ahmed Sarani, Mohakhali, Dhaka 1212, Bangladesh; email: saiful@icddrb.org

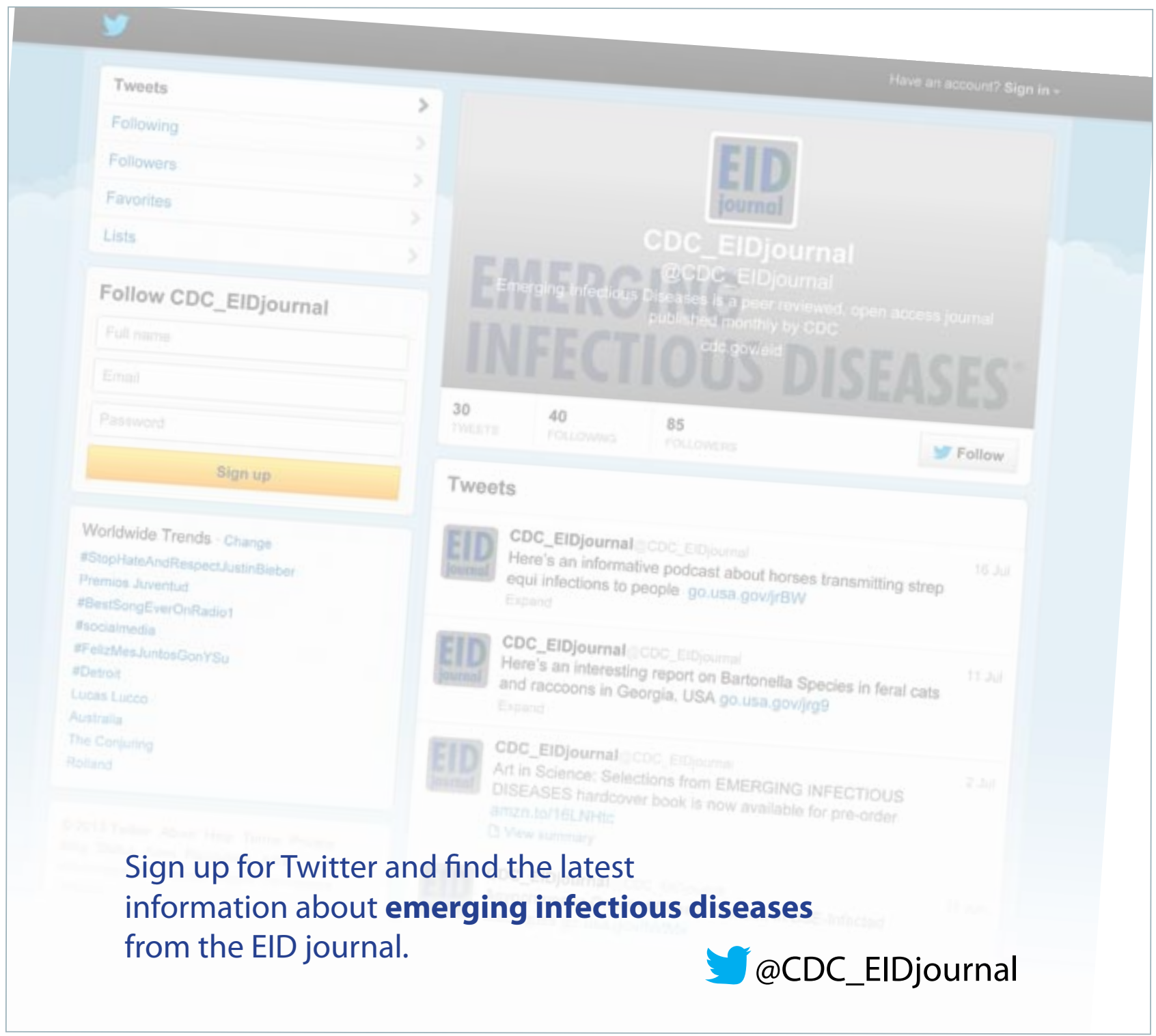

